\title{
La legislatio en los progymnasmata españoles del siglo XVI: del ejercicio escolar al texto literario
}

\author{
María Violeta Pérez Custodio
}

Este trabajo pretende profundizar en la recepción del ejercicio retórico conocido en latín como legislatio (confirmación o refutación de una ley) en la España del Renacimiento. La primera parte del artículo se centra en las dificultades de comprensión e interpretación a que debieron enfrentarse los humanistas que actualizaron este eficaz método de entrenamiento. Para tales estudiosos el principal obstáculo en el proceso exegético fue la localización de la estructura subyacente en el modelo aportado por Aftonio (la refutación de la ley que ordenaba castigar el adulterio con pena de muerte), ya que en él pudieron identificar con facilidad una sucesión de contradictiones y solutiones, pero no los tópicos argumentativos recomendados por el retórico griego. La segunda parte de este artículo estudia la utilización de la preceptiva de la propuesta de ley en la génesis de dos tipos diferentes de nuevos textos: composiciones de carácter escolar (modelos redactados a propósito para dotar a los manuales de progymnasmata de ejemplos desarrollados que pudieran ayudar a los estudiantes a la hora de saber cómo pasar de la teoría a la práctica) y textos literarios (un discurso de Palmireno y un texto de filosofía política de Juan de Mariana). La conclusión final de este análisis es que el uso de ciertas estrategias argumentativas específicas en textos literarios puede explicarse no como fruto de la libre imaginación del escritor, sino de su dominio de la antigua técnica retórica para el desarrollo de la legislatio.

Palabras Clave: Progymnasmata, legislatio, retórica, humanismo, latín renacentista.

This piece of work aims to study in depth the reception of the rhetorical exercise known in Latin as legislatio (confirmation or refutation of a law) in Renaissance Spain. The first part of this paper focuses on the difficulties of com- 
prehension and interpretation faced by humanists who updated this effective training method. For those scholars the main obstacle in the exegetical process was to find out the structure underlying the model provided by Aphthonius (the refutation of the law punishing adultery with death), as they could easily identify in it a series of contradictiones and solutiones, but not the argumentative topics recommended by the Greek rhetorician. The second part of this paper studies how the theoretical precepts about the legislatio were implemented to generate two different kinds of new texts: school compositions (models intentionally written to furnish progymnasmata handbooks with developed examples which could help students to know how to go from theory to practice) and literary texts (a speech by Palmireno and a text about political philosophy by Juan de Mariana). At the end it is concluded that the use of some specific argumentative strategies in literary texts can be explained not as a result of the writer's inspiration, but as a result of mastering the ancient rhetorical technique to develop the legislatio.

Keywords: Progymnasmata, Legislatio, Rhetoric, Humanism, Renaissance Latin.

Fecha de recepción: 8 de noviembre de 2011

Fecha de aceptación: 1 de marzo de 2012 


\section{María Violeta Pérez Custodio}

Universidad de Cádiz, España

\section{La legislatio en los progymnasmata españoles del siglo XVI: del ejercicio escolar al texto literario ${ }^{1}$}

\section{Los humanistas ante la preceptiva de la legislatio}

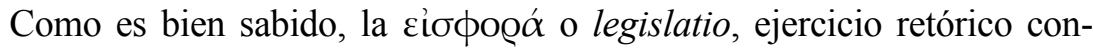
sistente en la confirmación o refutación de una ley, es el último de los progymnasmata según se nos han transmitido en las antiguas colecciones de Teón, Hermógenes, Aftonio y Nicolao. Su colocación al final de una serie que respondía al criterio de dificultad ascendente, venía justificada tanto por la materia especializada sobre la que debía versar la composición como por los tópicos de la argumentación, conectados con los ejercicios previos de la alabanza y el vituperio, la confirmación y refutación, el lugar común y la tesis. Ahora bien, pese a que la legislatio era el final de un camino de adiestramiento compositivo y la antesala de las declamaciones retóricas que abordaban una hipótesis judicial en toda regla,${ }^{2}$ los antiguos no se pusieron de acuerdo sobre sus señas de identidad.

\footnotetext{
${ }^{1}$ Este trabajo se ha realizado en el marco del Proyecto del Plan Nacional de I+D FFI2009-10133, y del Proyecto de Excelencia de la Junta de Andalucía con referencia PAI09-HUM-04858.

${ }^{2}$ Esta condición de ejercicio a caballo entre dos ciclos formativos se aprecia bien en la forma en que Aftonio lo describe, usando el término "gymnasma", "ejercicio", en lugar de "progymnasma", "ejercicio preparatorio", y definiéndolo como una auténtica hipótesis judicial completa con una serie de rasgos especiales. Véase Aftonio, Ejercicios, 264. Aprovecho esta nota para advertir al lector que las indicaciones de la
} 
Los indicios acerca de la falta de unanimidad en la tradición sobre los límites y características de la propuesta de ley no dejan lugar a dudas. Entre ellos dos resultan evidentes: por un lado, Hermógenes y Aftonio

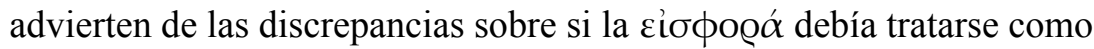
un ejercicio distinto a la tesis y defienden su individualidad, ${ }^{3}$ aunque el parecido entre los capítulos argumentativos que atribuyen a cada uno de estos progymnasmata establezca entre ellos un parentesco indiscutible. Por otro lado, existen importantes diferencias en los listados de lugares propios del ejercicio: así, en el manual de Teón — donde el capítulo se encuentra mutilado - se describe una estructura basada en ocho tópicos argumentativos (oscuridad, imposibilidad, falta de necesidad, argumento contrario, injusticia, estimación, inconveniencia y vergüenza) ${ }^{4}$ mientras que en el texto de Hermógenes se mencionan solo seis (claridad, justicia, legalidad, conveniencia, posibilidad y adecuación $)^{5}$ en el de Aftonio, cinco (legalidad, justicia, conveniencia y posibilidad, más el argumento contrario). ${ }^{6}$ Nicolao se refiere de forma genérica al uso de los "principios de argumentación finales" sin enumerarlos (Nicolao, Progymnasmata, 147).

Así pues, los estudiosos del XVI que recuperaron para el entrenamiento retórico los antiguos progymnasmata se toparon con un material cuya

obra (Ejercicios) y las páginas en las referencias a los textos antiguos de Teón, Hermógenes y Aftonio incluidos en este trabajo remiten a su localización en la traducción al español de María Dolores Reche, y que las referencias a los progymnasmata de Nicolao remiten a la traducción de E. Redondo, todo ello citado en la bibliografía final. Para las ediciones de los textos griegos usadas como base en las citadas traducciones al español, remito al lector a las de Spengel (para Teón), Rabe (para Hermógenes y Aftonio) y Felten (para Nicolao), también especificadas en la bibliografía. Por lo demás, el resto de traducciones que aparecen este trabajo, salvo indicación expresa, son mías.

3 “También incluyen algunos la propuesta de ley entre los ejercicios" (Hermógenes, Ejercicios, 198) y "También algunos han admitido que la propuesta de ley es un ejercicio" (Aftonio, Ejercicios, 264). Teón no se refiere a la diferenciación entre estos ejercicios. Nicolao, por su parte, no pone en relación la ley con la tesis, pero sí la diferencia del lugar común (Nicolao, Progymnasmata, 147).

${ }^{4}$ El estado de mutilación en que se nos ha transmitido el texto hace que solo se conserven las explicaciones relativas al principio de oscuridad. Véase Teón, Ejercicios, 150-153.

${ }^{5}$ Véase Hermógenes, Ejercicios, 199.

${ }^{6}$ Véase Aftonio, Ejercicios, 265. 
exégesis estaba plagada de dificultades. ${ }^{7} \mathrm{Y}$ a ellas debieron añadir una más: la que suponía disponer tan solo del modelo desarrollado por Aftonio - consistente en el rechazo de la ley que ordenaba condenar a muerte al adúltero sorprendido en flagrante delito (Aftonio, Ejercicios, 265-268) - como ejemplo práctico a partir del cual poder facilitar la génesis de nuevos textos. El otro ejemplo de propuesta de ley conservado en la tradición y perteneciente a la colección de Libanio ${ }^{8}$ (la defensa de la ley que prohibía a los hombres casarse con las esposas de sus hermanos fallecidos) no era conocido en la época. Por entonces solo se tenía acceso a una parte de los modelos de Libanio que fue atribuida a Teón y, en consecuencia, publicada tras los progymnasmata de este en las ediciones en griego de Angelo Barbato (ambas salidas en Roma en 1520) y en la bilingüe grecolatina de Joachim Kammermeister, más conocido como Camerarius (1541). ${ }^{9}$ Ese conjunto de modelos desarrollados de

${ }^{7}$ En el estudio que sigue sobre la recepción de la teoría de la legislatio he excluido los progymnasmata de Nicolao, dado que su influencia en la retórica renacentista aún no ha sido, por lo que yo sé, valorada. En todo caso, su escasa y tardía transmisión manuscrita, así como la falta de una edición impresa hasta el siglo XIX (la publicada en los Rhetores Graeci de Spengel en 1856, fue posteriormente superada por la de Felten en 1913, que trabajó usando ya el manuscrito del Museo Británico descubierto por Graeven) y la ausencia de referencias a estos progymnasmata en obras sobre la materia publicadas en el XVI permiten en principio deducir que muy pocos pudieron tener acceso al texto manuscrito en el Renacimiento y que su influencia en los tratadistas del XVI fue apenas significativa. Sobre la influencia de los ejercicios de Nicolao en su tiempo puede consultarse Fruteau de Laclos, Les progymnasmata de Nicolaos de Myra.

${ }^{8}$ El ejemplo ha sido considerado espurio y atribuido al Pseudo-Nicolao (Gibson, Libanius' Progymnasmata, 527-540).

${ }^{9}$ La colección de ejemplos hoy atribuida a Libanio (con mayores o menores sospechas de autenticidad según el ejemplo de que se trate) es mucho más extensa que la publicada en el XVI como obra de Teón. En la edición de Camerario (que se sirvió del texto editado por Barbato) el corpus iba precedido del epígrafe "Exempla superius expositorum exercitorum" y cerrado por el colofón "Exemplorum Theonis sophistae finis". Como ejemplo de la diferencia entre el corpus actual y el conocido en el XVI baste indicar que en el actual se incluyen 41 modelos de narraciones, frente a los solo tres de la edición de Camerario, y 27 modelos de etopeyas frente a los solo dos de la edición de Camerario. El material contenido en el conjunto de ejercicios que vio la luz en el XVI es el siguiente: fabula ("Fabula de lupis et ouibus"; "Fabula de equo et testudine"; "Fabula monedulae"), narratio ("Narratio de Deianira"; "Narratio de Hyacyntho"; "Narratio de Arethusa"), chria ("Alexander interrogatus a quodam in quo loco essent thesauri, ipsius demonstrauit amicos; Diogenes adolescentem conspicatus petulantem ipse pulsauit custodem tantum locutus: Cur tu ad hunc modum instituis?"; "Isocrates 
los distintos ejercicios, de dimensiones mucho más reducidas que el disponible en la actualidad y donde los modelos se encontraban ordenados siguiendo la misma sucesión que la preceptiva teórica, acababa con un ejemplo de tesis y no incluía ninguno de legislatio.

En España la primera muestra de cómo se entendió la preceptiva de este ejercicio se encuentra en el humilde librito que con la traducción latina de los catorce ejercicios de Aftonio firmada por Rodolfo Agrícola salió en Salamanca en 1550 en la imprenta de Andrés de Portonaris. Allí, en el capítulo de la legislatio los estudiantes podían aprender a estructurar con una receta simple un texto a favor o en contra de una ley. ${ }^{10}$ En esa fecha, sin embargo, hacía ya años que el mundo universitario español había dado muestras de interés por otro texto de entrenamiento retórico también de materia legal, pero de nivel muy superior. Me refiero a las declamaciones compiladas por Séneca el Viejo, impresas en Alcalá en 1539 por Juan Pérez de Toledo, Petreius, en un volumen que intituló Progymnasmata Artis Rhetoricae, una cum annotationibus in Senecae declamationes, controuersias et deliberatiuas, y que contenía, además de los textos entonces conocidos, una serie de capítulos adicionales sobre artificios retóricos. ${ }^{11} \mathrm{La}$ intención del catedrático de Alcalá no era sino ofrecer a los estudiantes un texto considerado un tesoro, tal

disciplinarum radices amaras illas quidem esse, fructus uero suaues dicere solebat"), sententia ("Dedecus est totam consultum stertere noctem"), destructio ("Non uerisimile esse ad Graecos peruenisse Chrysen"); assertio ("Verisimilia esse quae narrantur de armis Achillis"; "Quod uerisimilis sit expositio eorum quae de irato Achille traduntur"), locus communis ("Contra homicidam"; "In proditorem"), laudatio ("Laudatio Achillis"), uituperatio ("Vituperatio Achillis"), comparatio ("Comparatio nauigationis, id est, mercaturae maritimae et agriculturae"; "Comparatio Achillis et Diomedis"), ethopoeia ("Quibus uerbis ante Hectorem iacentem Andromache uti potuisse uideatur"; "Quid dicere potuerit Chiron, postquam audiuit inter uirgines esse Achillem"), descriptio ("Desciptio proelii peditum"; "Descriptio picturae in senatu"; "Descriptio ebrietatis"), propositum (“An matrimonium contrahendum sit"). Sobre las ediciones de Barbato y Camerario, véase Lana, I progymnasmi, 60-83. Más recientemente se trata sobre el texto de Camerario en Patillon, Aelius Theon, CXXXI-CXXXII.

${ }^{10}$ El capítulo sobre la legislatio ocupa los fols. 21r-23r.

${ }^{11}$ El índice reza así: "Quae continentur in progymnasmatis: Declamationes duae. Summa totius artis. De ductu. De elocutione. De figuris sententiarum. De tropis. De genere elocutionis et utilitate percipienda ex declamationibus. De declamandi ratione. De diuisione et statu. De coloribus. Libri declamationum, controuersiarum, deliberatiuarum". 
como indica en la carta dedicatoria de la citada obra ("uisus est mihi thesaurus non uulgaris", Progymnasmata, fol. Aaii v.) para la práctica de la composición de discursos de debate legal. Sucedió, pues, que de las prensas españolas salió un libro sobre las complejas estrategias propias de elaborados textos legales, antes que un manual de ejercicios básicos donde aprender el paso preliminar en la refutación o confirmación de una ley. ${ }^{12}$

El citado librito salmantino de 1550 era una edición minimalista donde la versión latina de Agrícola se ilustraba con unas escuetísimas indicaciones marginales, que en el modelo de legislatio ("Accusatio legis iubentis adulterum in ipso adulterio interfici", fol. 21r.) marcaban una estructura dividida en 'proemium', 'contrarium' y cuatro bloques de 'contradictiones' y 'solutiones', tal y como aparece ya en la edición coloniense de la traducción de los ejercicios de Aftonio debida a Rodolfo Agrícola, que se imprimió en 1539 con la abundantísima exégesis de Alard de Amsterdam, ${ }^{13}$ y tal como se repitió en la posterior edición donde Lorich contaminó las traducciones de Agrícola y Cataneo, dando como resultado un texto híbrido reimpreso en numerosas ocasiones a partir de $1542 .{ }^{14}$

Como puede verse en el cotejo que sigue, la localización de los bloques de contradicciones y soluciones correspondía a los mismos lugares del texto, excepción hecha de la última pareja, cuya indicación falta en

${ }^{12}$ En Europa hubo un temprano interés por las declamaciones legales. Algunas de las Declamationes maiores atribuidas a Quintiliano se imprimieron en Roma en 1475 a cargo de Calderini, edición que fue seguida de varias más hasta llegar en 1580 a la parisina de Pierre Pithou (M. Fab. Quintiliani declamationes, quae ex CCCLXXXVIII supersunt, CXLV ex uetere exemplari restitutae, Calpurnii Flacci Excerptae X, rhetorum minorum LI, nunc primum editae, Dialogus de oratoribus, siue de causis corruptae Eloquentiae) que ofrecía por primera vez la colección de 145 piezas.

${ }^{13}$ Los Aphthonii sophistae progymnasmata Rodolpho Agricola Phrisio interprete salieron dentro del segundo volumen de las De inuentione dialectica lucubrationes bajo los cuidados Alard de Amsterdam, discípulo de Agrícola y que, según dice en la portada de la obra, dispuso del autógrafo a partir del cual enmendó e ilustró el texto. En el ejercicio de la legislatio, sin embargo, el comentarista no hizo preceder el ejemplo de ninguna anotación que indicara el tema del mismo (Agrícola, Progymnasmata, 69). Sobre la versión hecha por Agrícola de los ejercicios de Aftonio, véase Jardine, "Distinctive Discipline", 48-54.

${ }^{14}$ Sobre la naturaleza de la traducción latina ilustrada por Lorich y su enorme éxito editorial, véase Clark, "The Rise". 
los ejemplares que he podido consultar del texto de 1539 , tal vez por un error de imprenta: ${ }^{15}$

\begin{tabular}{|c|c|c|c|}
\hline $\begin{array}{l}\text { ANOTACIONES } \\
\text { MARGINALES }\end{array}$ & $\begin{array}{c}\text { A. DE AMSTERDAM } \\
1539\end{array}$ & $\begin{array}{l}\text { R. LORICH } \\
1542\end{array}$ & $\begin{array}{c}\text { SALAMANCA } \\
1550\end{array}$ \\
\hline Proemium & $\begin{array}{l}\text { Nec mihi uidetur } \\
\text { per omnia lex ista } \\
\text { laudanda }[\ldots]\end{array}$ & $\begin{array}{l}\text { Nec mihi uidetur } \\
\text { per omnia lex ista } \\
\text { laudanda }[\ldots]\end{array}$ & $\begin{array}{l}\text { Nec mihi uidetur } \\
\text { per omnia lex ista } \\
\text { laudanda }[. . .]\end{array}$ \\
\hline Contrarium & $\begin{array}{l}\text { Aliae sane leges } \\
\text { quaecumque de- } \\
\text { mum eae sunt }[\ldots]\end{array}$ & $\begin{array}{l}\text { Aliae sane leges } \\
\text { quaecumque de- } \\
\text { mum eae sunt }[\ldots]\end{array}$ & $\begin{array}{l}\text { Aliae sane leges } \\
\text { quaecumque de- } \\
\text { mum eae sunt }[\ldots]\end{array}$ \\
\hline Contradictio & $\begin{array}{l}\text { Sane, inquit, } \\
\text { sed magnae sunt } \\
\text { moechorum ini- } \\
\text { uriae }\end{array}$ & $\begin{array}{l}\text { Sane, inquit, } \\
\text { sed magnae sunt } \\
\text { moechorum iniur- } \\
\text { iae }[\ldots]\end{array}$ & $\begin{array}{l}\text { Sane, inquit, } \\
\text { sed magnae sunt } \\
\text { moechorum iniur- } \\
\text { iae }[\ldots]\end{array}$ \\
\hline Solutio & $\begin{array}{l}\text { Quid autem? Si- } \\
\text { cariorum an non } \\
\text { longe grauius } \\
\text { scelus? }[\ldots]\end{array}$ & $\begin{array}{l}\text { Quid autem? Sicar- } \\
\text { iorum an non longe } \\
\text { grauius scelus? [...] }\end{array}$ & $\begin{array}{l}\text { Quid autem? Sicar- } \\
\text { iorum an non longe } \\
\text { grauius scelus? [...] }\end{array}$ \\
\hline Contradictio & $\begin{array}{l}\text { Et quid refert, } \\
\text { inquit, occidam } \\
\text { adulterum, an iu- } \\
\text { dicibus tradam, si } \\
\text { utraque uia morte } \\
\text { poenas luet? [...] }\end{array}$ & $\begin{array}{l}\text { At quid refert, in- } \\
\text { quit, occidam adul- } \\
\text { terum, an iudicibus } \\
\text { tradam, si utraque } \\
\text { uia morte poenas } \\
\text { luet? [...] }\end{array}$ & $\begin{array}{l}\text { Et quid refert, in- } \\
\text { quit, occidam adul- } \\
\text { terum, an iudicibus } \\
\text { tradam, si utraque } \\
\text { uia morte poenas } \\
\text { luet? [...] }\end{array}$ \\
\hline Solutio & $\begin{array}{l}\text { Hoc interest, sci- } \\
\text { licet, quod inter } \\
\text { tyrannum atque } \\
\text { leges quodque } \\
\text { inter rempublicam } \\
\text { et regnum }[. . .]\end{array}$ & $\begin{array}{l}\text { Quantum inter ty- } \\
\text { rannum ac legem, } \\
\text { popularem statum } \\
\text { ac unius principa- } \\
\text { tum differt, tantum } \\
\text { ista inter se diuersa } \\
\text { sunt }[. . .]\end{array}$ & $\begin{array}{l}\text { Hoc interest, sci- } \\
\text { licet, quod inter } \\
\text { tyrannum atque } \\
\text { leges quodque inter } \\
\text { rempublicam et } \\
\text { regnum [...] }\end{array}$ \\
\hline
\end{tabular}

${ }^{15}$ En los ejemplares que he podido consultar falta la indicación del cuarto bloque, pero desconozco si puede haber distintos estados de esta edición y, en consecuencia, si puede haber ejemplares donde esta falta se encuentre subsanada. 


\begin{tabular}{|c|c|c|c|}
\hline Contradictio & $\begin{array}{l}\text { Est, inquit, sed } \\
\text { grauiores dabit } \\
\text { poenas subito } \\
\text { peremptus }[. . .]\end{array}$ & $\begin{array}{l}\text { Esto, inquit, sed } \\
\text { grauiores dabit } \\
\text { poenas subito pe- } \\
\text { remptus }[\ldots]\end{array}$ & $\begin{array}{l}\text { Est, inquit, sed } \\
\text { grauiores dabit } \\
\text { poenas subito pe- } \\
\text { remptus }[\ldots]\end{array}$ \\
\hline Solutio & $\begin{array}{l}\text { At contra porro } \\
\text { habebit, si iudice- } \\
\text { tur [...] }\end{array}$ & $\begin{array}{l}\text { At contra porro ha- } \\
\text { bebit, si iudicibus } \\
\text { subiicietur }[\ldots]\end{array}$ & $\begin{array}{l}\text { At contra porro } \\
\text { habebit, si iudice- } \\
\text { tur }[\ldots]\end{array}$ \\
\hline Contradictio & & $\begin{array}{l}\text { Res atrox est } \\
\text { adulter, omnium } \\
\text { scelerum magni- } \\
\text { tudinem super- } \\
\text { gressus }[\ldots]\end{array}$ & $\begin{array}{l}\text { At grauis est adul- } \\
\text { ter omniumque } \\
\text { scelerum magni- } \\
\text { tudinem super- } \\
\text { gressus [...] }\end{array}$ \\
\hline Solutio & & $\begin{array}{l}\text { Coarguatur ergo } \\
\text { prius quam occi- } \\
\text { datur iudiceturque } \\
\text { potius quam }[. . .]\end{array}$ & $\begin{array}{l}\text { Coarguatur ergo } \\
\text { prius, hinc occi- } \\
\text { datur iudiceturque } \\
\text { potius }[. . .]\end{array}$ \\
\hline
\end{tabular}

Lo llamativo de esta estructura es que no contenía indicación alguna de en qué puntos del texto se habían utilizado los cuatro principios de argumentación prescritos por Aftonio (legitimidad, justicia, utilidad y posibilidad) para la construcción del esqueleto argumentativo de la composición: "Tractabis eam capitius eisdem quibus negotialem: legitimo, iusto, utili, possibili" (Agrícola, Progymnasmata, 68). Su persistencia, sin embargo, se atestigua años después en la versión de los ejercicios de Aftonio firmada por Joachim Camerarius (1567), donde no se marcaron en las anotaciones marginales la ubicación del exordio ni del argumento contrario, pero sí la de cuatro bloques de objeciones y soluciones que coincidían con los lugares ya indicados (Camerarius, Libellus progymnasmatum, 60-65).

Cuando seis años después de la edición salmantina de 1550 el Brocense hizo imprimir también en la misma ciudad otro librito con la versión de Agrícola y unos escasos escolios extractados principalmente de los de Alard de Amsterdam y Lorich (Ureña, "Algunas consideraciones", 317-328), la estructura que volvió a aparecer anotada en los márgenes del ejemplo repitió la previamente impresa: la división en los 
cuatro bloques de objeciones y respuestas en idénticos lugares del texto, pero ninguna pista sobre en qué párrafos se utilizaban los citados cuatro principios de argumentación prescritos por el griego (Sánchez de las Brozas, Progymnasmata, 28v.-29r).

La traducción latina de Francisco de Escobar, salida en Barcelona en 1558, marcó, sin embargo, una interesante diferencia en la actualización humanista de la teoría y práctica de la legislatio en España. Escobar era un pensador independiente, que criticó de forma abierta las traducciones contemporáneas que no consideraba fiables ni elegantes, pero que habían alcanzado un enorme éxito académico en Europa (Pérez Custodio, "La traducción al latín", 121-144). Al igual que en las ediciones precedentes salmantinas, en el librito de Escobar la exégesis del texto de Aftonio estaba limitada a unas escuetas notas marginales que en la parte teórica hacían las veces de epígrafes temáticos ${ }^{16}$ y que en el modelo iban indicando la estructura del mismo. Gracias a esas notas podemos saber que el humanista vio en el modelo de Aftonio un andamiaje retórico diferente al propuesto por Agrícola y sus seguidores. Según Escobar, el texto se componía de dos exordios sucesivos ("primum exordium" y "secundum exordium"), una "epagoge per enumerationem" (es decir, una sucesión de ejemplos indubitables que apoyaban la veracidad de lo defendido), y tres bloques (no cuatro) de objeciones con resoluciones, donde identificó el uso de tres de los principios argumentativos preceptuados por Aftonio: los de legitimidad y justicia vinculados a la segunda objeción ("a legitimo" y "a iusto"), y el de utilidad ("ab utili"), localizado en las últimas líneas del texto.

Escobar, pues, propuso su propia alternativa a una estructura que, pese a venir avalada por el prestigio de Rodolfo Agrícola, carecía de indicaciones sobre algo tan fundamental como la localización en el texto de los principios argumentativos que el retórico griego había prescrito. El catedrático de Barcelona no hizo, sin embargo, sino seguir un camino interpretativo que había sido desbrozado previamente. Así, en la primera versión latina impresa de los ejercicios de Aftonio, la de Juan María Cataneo (Bolonia, 1507), aparecían ya unas notas marginales

${ }^{16}$ Los dos lemas rezan así: "Quae legislationis natura" y "Legislationis definitio" (Escobar, Aphthonii sophistae Progymnasmata, 86). 
que indicaban el lugar del "proemium", del "argumentum contrarium" y de cinco bloques de "contradictiones" y "solutiones", tras los cuales se añadieron los términos "legitimo", "utili", "possibili" y "iusto", para señalar qué frases del texto desarrollaban estos puntos justo al final del ejemplo (Cataneo, Progymnasmata, cii v.). Aunque la localización de los principios argumentativos no coincida en las versiones de Cataneo y Escobar, resulta claro que para estos humanistas su identificación era algo que no debía escatimarse al lector.

La interpretación de Escobar fue, pues, la primera muestra de espíritu crítico que conozco en España en torno al tema de la legislatio. Pero tras ella vinieron otras dos. Así, en 1567 Juan de Mal Lara publicó en Sevilla unos escolios a Aftonio (In Aphthonii progymnasmata scholia) donde dedicó un párrafo a expresar su opinión personal sobre la cuestión que abre el ejercicio en los antiguos: la de si la propuesta de ley debía constituir o no un ejercicio independiente. En él el humanista indicaba que, según su parecer, la legislatio no tenía suficiente entidad propia y, por ello, podía tomarse como un pariente de la tesis, el elogio y el vituperio:

Ex iis, quae in thesi considerantur, iam apparet et leges partim ad theseis, partim ad hypotheseis referendas, ut autor docet: ad theses, si lex eius modi esse dicatur, quae hactenus desiderata fuerit, aut in dissuasione, quae superflua, itemque quae bona, utilis, speciosa, contrariaue sit; ad hypotheseis uero, si quasi addita persona lex Solonis aut Licurgi laudetur, aut uituperetur, sed, ut omnia dicam quod sentio, proprium de legibus caput faciendum non fuit, nam ad probationes, refutationes uel laudemque ac uituperationem haec tractatio tota est referenda (Mal Lara, scholia, fol. N2 v.). ${ }^{17}$

17 “A partir de las consideraciones que se hacen en la tesis queda ya claro que unas leyes deben tratarse como tesis y otras como hipótesis, según enseña el autor. Como tesis, si se dijera que es la clase de ley que hasta ahora hemos echado en falta, o que es superflua, si fuera una disuasión (y casos similares serían decir que es buena, útil, brillante, o perniciosa); como hipótesis, en cambio, si se hiciera la alabanza o el vituperio de la ley como se haría añadiendo al legislador (Solón o Licurgo), aunque, por decir completamente lo que pienso, no se debió idear un capítulo independiente sobre las leyes, pues para toda esta amplificación se puede recurrir a las confirmaciones y las refutaciones, o a la alabanza y el vituperio". 
Sin embargo, la opinión de Mal Lara no era tan personal como quiso hacer creer a sus lectores con la expresión "ut omnia dicam quod sentio". Era, en efecto, una opinión impresa por vez primera en España, pero que no hacía sino reproducir de manera casi literal un párrafo de los Elementa Rhetoricae de Joachimus Camerarius, un libro editado por vez primera en Leipzig en 1540 y que, antes de la publicación de los Scholia in Aphthonii progymnasmata de Mal Lara en 1567, ya había conocido varias reediciones. ${ }^{18} \mathrm{El}$ cotejo entre la fuente y la copia habla por sí mismo:

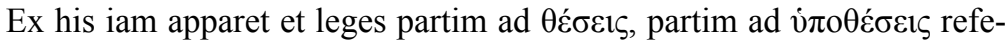
rendas, ut et Aphthonius docuit. Ad theses, si lex eiusmodi esse dicatur, quae hactenus desiderata fuerit, aut in dissuasione, quae superflua. Itemque quae bona, utilis, speciosa contrariaue sit. Ad vं $\pi 0 \theta \dot{\varepsilon} \sigma \varepsilon ı \varsigma$ uero, si quasi addita persona lex Solonis aut Lycurgi laudetur aut uituperetur. Sed, ut omnino dicam quod sentio, propriam de legibus caput faciendum non fuit. Nam ad probationes refutationesue, laudemque ac uituperationem haec tratatio tota est referenda (Camerarius, Elementa Rhetoricae, $320)$.

Como cabía esperar tras este pronunciamiento, Camerario no dedicó en su obra ningún capítulo independiente al tratamiento de la propuesta ley, una opción que otros humanistas también compartieron. Tal es el caso de Antonio Lull, el balear que publicó en 1548 en Basilea unos Progymnasmta Rhetorica ${ }^{19}$ donde no incluyó la legislatio como ejercicio autónomo, sino como una variante de la tesis:

In ferenda lege et abroganda eadem tractamus. Sed praemittendum illud in principio, iam debuisse olim fuisse latam legem aut abrogatam (si abrogatam cupis), ne illa accidissent quae nunc deflemus. Occupatio namque haec multum momenti habet ad faciendam fidem in deliberationibus (Lull, Progymnasmata, 38 ). ${ }^{20}$

${ }^{18}$ Entre otras, las de Basilea, Oporini, 1541, 1545 y 1551, y Leipzig, Vögelin, 1562 y 1564.

${ }^{19}$ La obra conoció varias ediciones: Lyon, 1550; Basilea, 1551 y Lyon, 1572.

20 "La defensa de una ley y su derogación se amplifican de la misma manera. Pero hay que decir al principio que hace ya tiempo que debería haberse propuesto o derogado 
Pero, sin duda, el mejor representante del espíritu crítico en la recepción de la teoría y práctica de la legislatio en España fue Pedro Juan Núñez, autor de unos Progymnasmata, id est, praeludia quaedam oratoria ex progymnasmatis potissimum Aphthonii, impresos por vez primera en Barcelona en 1578 dentro de sus Institutiones Rhetoricarum libri quinque. Aunque, como el título del libro advertía, el contenido dependía principalmente del texto de Aftonio, el estudio interno de la obra ha permitido saber que el humanista valenciano, además de buen conocedor de estos ejercicios, estaba familiarizado con los de Teón a través del volumen bililingüe grecolatino de Camerario de 1541, y con los de Hermógenes, que citaba por la versión latina de Prisciano (Pérez Custodio, "Los progymnasmata de Teón" y "La recepción”). Así pues, cuando Núñez redactó el capítulo de la legislatio en sus ejercicios retóricos, ${ }^{21} \mathrm{se}$ ocupó de poner de manifiesto la falta de unanimidad de los antiguos al preceptuar la amplificación de esta y tomó postura propia decantándose por seguir la senda de las instrucciones legibles en Aftonio y deducibles de su modelo. Ahora bien, a la hora de transmitir a sus lectores la fórmula para componer este tipo de textos, el humanista no reprodujo la preceptiva teórica de Aftonio sobre los cuatro capítulos argumentativos, sino la estructura a base de contradicciones y soluciones que podía identificarse en el ejemplo. Para Núñez, pues, la fórmula que se veía empleada en la práctica era la que había que transmitir a los alumnos:

Quamquam partes huius progymnasmatis uarie traduntur a scriptoribus, ea tamen ratio commodior uidetur quae ex praeceptis atque exemplo Aphthonii colligi potest, quattuor nimirum esse huius progymnasmatis partes: exordium, contrarium, oppositiones cum solutionibus atque epilogum. Exordium paullo prolixius quam in thesi adhibendum est, contrarium ut in communi loco, oppositiones et solutiones ut in thesi tractandae; epilogus ex capitibus quae pertinent ad finem sumendus est (Núñez, Progymnasmata, 75$)^{22}$

(si deseas que se derogue), para que no hubiera sucedido lo que ahora lamentamos. Esta prolepsis, sin duda, es muy efectiva para producir credibilidad en las deliberaciones".

${ }^{21}$ Puede encontrarse una traducción al español del capítulo en Artaza, Antología, 79-83.

22 "Aunque los escritores nos han transmitido de manera diferente las partes de este ejercicio, parece que la estructura más clara es la que puede deducirse de los preceptos 


\section{De la preceptiva al texto escolar y al texto literario}

Hasta aquí lo relativo a los escollos interpretativos con que se toparon los humanistas españoles en la recepción de la teoría y práctica de la legislatio a través del puente que supusieron las autoridades de fuera del país. Pasaré ahora al análisis de cómo gestionaron el tránsito de la preceptiva a la génesis de nuevos ejemplos en que los estudiantes pudieran encontrar materia de imitación. El elemento crucial de este proceso fue la recreación de los modelos modernos de legislatio que Lorich había insertado en su manual. Dos eran propios (la defensa de la ley Opia y de la ley que ordenaba a los hijos hacerse cargo del sustento de los padres) ${ }^{23}$ y uno, ajeno (la defensa de una ley que en Suiza penaba la incitación a beber), salido de la pluma de Peter Schade, Petrus Mosellanus. ${ }^{24}$ Los dos modelos del alemán aparecían con lemas marginales que revelaban su arquitectura interna. Esa estructura constaba en el primer caso de exordio, argumento "a contrario", argumentos de evidencia, legitimidad, justicia y utilidad, y, por último, una objeción con su correspondiente solución (Lorich, Progymnasmata, 489-491). En el segundo, había un esquema más largo y complejo donde, tras el exordio, seguían cinco bloques de objeciones y soluciones en los que se entremezclaban los argumentos de conveniencia, legitimidad, justicia y utilidad, posibilidad y facilidad (Lorich, Progymnasmata, 491-497). En definitiva, Lorich había seguido la preceptiva aftoniana que suponía la utilización de bloques de objeciones y soluciones y de principios de argumentación (de hecho, incluso utilizó más de los enumerados por Aftonio) y había anotado el uso de estos recursos compositivos en los márgenes de sus composiciones, pese a que en los del modelo antiguo

y el ejemplo de Aftonio, a saber, que las partes de este ejercicio son indiscutiblemente cuatro: el exordio, el argumento contrario, las objeciones con sus respuestas y el epílogo. Hay que incluir un exordio un poco más extenso que en la tesis; el argumento contrario ha de ser como en el lugar común; las objeciones y sus respuestas hay que amplificarlas como en la tesis; el epílogo hay que tomarlo de los tópicos que son adecuados para la parte final".

23 "Exemplum confirmationis Legis Oppiae" (489) y "Secundum exemplum confirmationis legis, quae iubet ut liberi parentes alant, aut uinciantur" (491).

24 "Tertium exemplum comprobationis legis, qua apud Heluetios cauetur ne quis inuitatione ad bibendum urgeatur, authore Petro Mosellano" (498). 
no había indicado la presencia de dichos argumentos (Lorich, Progymnasmata, 477-483). Este hecho parece sugerir que la omisión de los capítulos argumentativos en las citadas anotaciones marginales de Lorich vino causada más por la dificultad de su localización que por la falta de importancia a ellos atribuida.

En ambas composiciones las leyes abordadas tenían detrás una conocida literatura: en el caso de la ley sobre el gasto, el principal punto de referencia era Tito Livio, quien en su $A b$ urbe condita $(34,1-8)$ había recreado la controversia en torno a la derogación de la ley Opia y el discurso de Catón a favor de su mantenimiento. ${ }^{25}$ Por su parte, la defensa de la ley que obligaba a los hijos a ocuparse de los padres era también un tema rescatado de la antigüedad, que se abordaba en la quinta pieza incluida en las Declamationes maiores de Quintiliano, "Liberi parentes in egestate aut alant aut uinciantur", y cuya aparición recurrente está bien documentada en el Renacimiento, donde este tema se consideró una materia de derecho natural, ${ }^{26}$ recogida, entre otros, por Erasmo en sus Adagia y Alciato en sus Emblemata, de donde pasó, por ejemplo, a la Philosophía vulgar de Juan de Mal Lara y a la Silva de varia lección de Pedro de Mexía (Merino, "El Brocense”, 158-163 y Antón, "Emblemática", 199-233). El propio Lorich había tratado ya el tema del deber de los hijos hacia los padres, representado en el mundo animal por la cigüeña, en el encomio de la Universidad de Marburgo (Progymnasmata, 279-310), imitado en España por Alfonso de Torres en el elogio de la Universidad de Alcalá incluido en sus Rhetoricae Exercitationes en 1569 (264-281).

El tercer ejemplo que Lorich insertó en su manual era el segundo de los dos que el afamado profesor de Leipzig, Peter Schade, había compuesto para ilustrar la propuesta de ley en sus De primis apud rhetorem exercitationes, impresos a partir de 1523. La flexibilidad con la que Moselano aplicó en la práctica la receta teórica resulta patente. Así, tras indicar con minuciosidad la estructura por la que debía avanzar el texto,

${ }^{25}$ Sobre este episodio legal de la derogación de la ley Opia, véase también la colección de Dicta et facta memorabilia $(9,1,3)$ de Valerio Máximo.

${ }^{26}$ Así se trata en Budé, Annotationes, fol. X v. 
Reprehenditur autem lex his fere rationibus, si eius latorem probabiliter crimineris, si contrarium recte haberi ostendas, si efficias ut quod lege ipsa statuitur, pugnare uideatur partim cum aliis legibus, partim cum aequitate, partim cum utilitate; si causam ob quam ferri uideatur parum ualere, si denique omnino fieri non posse, aut si possit, non sine periculo difficultateque hoc tentari. Eadem ratio in contrarium mutata in legibus comprobandis est seruanda (Mosellanus, De primis, fol. F r.). ${ }^{27}$

Moselano insertó sus modelos sin que nada indicara en los márgenes la localización de los argumentos aftonianos previamente prescritos. Así, en el primero de los textos, "Reprehensio legis Iuliae iubentis adulterum in ipso scelere deprehendum statim occidi" (De primis, fol. F r.), inspirado sin duda en el tema del modelo del griego, el erudito identificó la división de un largo exordio ("reprehensio latoris", "pugnantia" y "exemplum"), el "argumentum contrarium" y dos objeciones (con la identificación de "refutatio"), así como el uso de dos ejemplos, un símil, una comparación y una sentencia con los que hermoseó la estructura. En el segundo ejemplo, la "Comprobatio legis qua apud Heluetios cauetur ne quis inuitatione ad bibendum urgeatur" (De primis, fol. Fiii r.), Moselano ni siquiera anotó la presencia del argumento contrario (pese a haber indicado en la receta previa que era parte fundamental de la defensa de una ley), pero sí la de un símil, un ejemplo y un proverbio, que intercaló en el texto, aunque de estos adornos complementarios nada se decía en el precepto.

No conozco en España imitaciones de los dos modelos de Moselano, pero sí es evidente la influencia de los dos de Lorich en los insertos por Alfonso de Torres en sus Rhetoricae Exercitationes: la defensa de la antigua legislación romana sobre el gasto (Rhetoricae Exercitationes, 360-369) y la refutación de la Ley de las Doce Tablas que permitía descuartizar al acreedor moroso (370-379). Los temas, cuya fuente común,

\footnotetext{
27 "La refutación de la ley, en cambio, se hace con estos argumentos: si censuraras con credibilidad al legislador, si hicieras ver que lo contrario es correcto, si consiguieras que parezca que lo que establece la propia ley choca en parte con otras leyes y en parte con la equidad y la utilidad; si pareciera que la causa por la cual se presenta no tiene peso; si pareciera, en fin, que no puede ser en absoluto, o que, si pudiera ser, no podría intentarse sin peligro y dificultad. Hay que mantener esta misma estrategia, tomándola al contrario, para confirmar las leyes".
} 
como el humanista especifica a sus estudiantes, eran las Noctes Atticae de Aulo Gelio, ${ }^{28}$ estaban tomados de los dos listados de ejemplos proporcionados por Lorich, donde aparecían enumeradas distintas leyes de la antigüedad romana: la ley Roscia, la ley del Talión y la ley Cincia para ejercitar la "confutatio legis", y la "lex Sumptuaria", la "lex Fusia" y la "lex Voconia" para la "confirmatio legis". ${ }^{29}$ Se trataba de leyes de fácil documentación, cuyas referencias el estudiante podía encontrar ya especificadas por el propio Lorich y podía localizar en los repertorios de la época sobre legislación antigua. ${ }^{30}$

La defensa de la ley romana sobre el gasto compuesta por Torres era a todas luces una reelaboración de la defensa de la ley Opia compuesta por Lorich, que, como he dicho, se había ocupado de marcar en los márgenes de sus dos modelos propios una estructura coincidente con la prescrita en la teoría. Pero Torres fue incluso más cuidadoso que Lorich en la coincidencia entre la receta y el resultado práctico: estructuró tanto el primer como el segundo modelo con un mismo esquema que seguía al pie de la letra los cuatro puntos de argumentación prescritos por Aftonio — legitimidad, justicia, utilidad y posibilidad—, y utilizaba la

28 "Exemplum confirmationis legis sumptuariae, quae unicuique sumptus iuxta rationem census praescribebatur. De qua Gellius lib. 2, cap. 24, Macrobius etiam lib. 3, cap. 17" (360) y "Exemplum refutationis legis Duodecim Tabularum, quae iubebat corpus dissecari eius multa creditoribus deberet nec esset soluendo, ut singuli singulas partes corporis auferrent. De qua Gellius lib. 20, cap. 1" (370).

29 "Confutatio legis: Rosciae, qua Roscius Otho cauit, ne quis in ordine equestri spectacula uideret, nisi haberet sestertia quadraginta; Talionis, et eius quae iubebat corpus dissecari eius qui multa creditoribus deberet, nec esset soluendo. Gell. Lib. 20. cap. 1; Cinciae, quam Cincius tulit, qua cauebatur, ne quis ob causam orandam pecuniam acciperet, aut domum, cuius suasor Q. Fabius admodum senex, ut ait Cicero, in Catone Maiore. Confirmatio legis: Sumptuariae, de qua Gellius lib. 2, cap. 24; Fusiae, qua malis ac perniciosis legibus resistebatur; Voconiae, quam suasit M. Cato, ut ait Cicero in Senectute. Vide Gellium lib.7, c. 6; Oppiae, quam tulit M. Oppius, ne mulieres superfluo ornatu uterentur, neue pilentis, id est, rhedis pensilibus ueherentur. Vide Liuium in principio quarti libri Macedon" (Progymnasmata, 487-488).

${ }^{30}$ Como se lee en el texto aducido en la nota precedente, Lorich remitió a los estudiantes a Gelio, Cicerón y Livio. Recuérdese, además, la utilidad para este tipo de documentación de obras como el Liber de Legibus de Paulo Manucio, dotado al final de un Index rerum memorabilium que permitía localizar con facilidad la información sobre el thesaurus de leyes contenido en la obra, entre las que figuran la "lex Oppia", la "lex Roscia", la "lex Voconia", la "Lex Duodecim Tabularum", la "lex Fusia" y las "Leges Sumptuariae". 
alternancia de objeciones y soluciones, todo ello debidamente indicado por los correspondientes lemas.

El protagonismo, en fin, de la ley Opia como motivo de ejercitación retórica aparece de nuevo años después en los progymnasmata incluidos por Juan Lorenzo Palmireno en la Segunda parte del Latino de repente (Valencia, 1573), que no eran sino una síntesis encubierta de los de Lorich (Pérez Custodio, "Sobre el origen"). En estos ejercicios el humanista español incluyó como modelo único de legislatio el texto de la defensa de la ley Opia del profesor de Marburgo traducido al romance y publicado con unas indicaciones marginales que, lógicamente, marcaban en la estructura los mismos hitos que aparecen en el original: un exordio "a laude legislatoris", el argumento "a contrario" y los argumentos "a manifesto", "a legitimo", "a iusto", "ab utili", una "obiectio" ("contradictio" en el ejemplo de Lorich) seguida de la correspondiente "solutio" y una "conclusiuncula" ("conclusio" en el ejemplo de Lorich) (Palmireno, Segunda Parte, 92-94).

Pedro Juan Núñez, en cambio, eligió para el modelo de legislatio de sus progymnasmata una ley de carácter bien distinto. Se trataba de la refutación de una norma universitaria contemporánea que prohibía el uso docente del método del dictado (Núñez, Progymnasmata, 75-78), los "dictata", una práctica común en las universidades europeas desde el siglo XIV en las materias de Artes y Filosofía, y consistente en la lectura en clase por parte del profesor de unos apuntes o explicaciones de los que los alumnos tomaban nota. ${ }^{31}$ Aunque en el ejemplo Núñez vitupera una ley cuya aprobación no sitúa en ninguna universidad determinada y ubica de forma muy general en el tiempo ("superioribus annis", "años atrás"), el humanista estaba tratando sobre un asunto que le concernía muy directamente y que podemos contextualizar gracias a otros dos discursos escritos años antes, en 1572, por su colega y amigo Juan Lorenzo

\footnotetext{
${ }^{31}$ La elección de una ley actual como materia del ejercicio de la propuesta de ley tiene un antecedente en los ya citados ejercicios retóricos de Moselano, quien, como he indicado anteriormente, incluyó un modelo de legislatio consistente en la defensa de una ley recién salida en Suiza por la que se penaba la incitación a beber. Se trataba de un tema del momento, enmarcado en la normativa que en esas fechas se implantó en la Suiza calvinista para la enmienda de las costumbres. Así, el Consejo de Zürich limitó, por ejemplo, los horarios de actividad de las tabernas para tratar de disminuir la afición de sus conciudadanos por la bebida.
} 
Palmireno sobre la misma materia: dos "orationes aduersariae" sobre la conveniencia de abolir o no el uso de los "dictata" (Palmireno, Discursos, 142-161 y 162-179), que fueron puestas en escena por sendos estudiantes en una especie de debate público organizado por el humanista para exponer los pros y contras del método en el Studi General de Valencia, donde se había aprobado una ley que los prohibía. ${ }^{32}$

La postura de Núñez en defensa de esta metodología no era artificial, sino fruto de su experiencia como docente que practicaba el dictado. El humanista no era ya profesor en Valencia cuando se abolieron los dictados en torno a $1572,{ }^{33}$ pero sí había impartido en dicha universidad clases de Súmulas, Filosofía, Oratoria y Retórica en dos periodos anteriores (entre 1551-56 y 1561-63) y había sido colega de Palmireno, con quien además había coincidido en Zaragoza de 1557 a $1561 .{ }^{34}$ Sabemos que Núñez se había servido de los "dictata" en sus clases de filosofía y oratoria en las aulas valentinas, porque así lo atestigua el propio Palmireno, quien en uno de esos discursos lo menciona entre el grupo de los insignes profesores de la universidad valenciana practicantes de este método: "Quis nobis clarissimos doctores Polum medicum, Pascualium philosophum et Viñas oratorem exhibuit? Dictata Nuñesii." (Discursos, $152)^{35}$ y en el otro vuelve a citarle entre el conjunto de eruditos docentes de Valencia que habían alcanzado un extraordinario renombre por su enciclopédica cultura cuando todavía no eran conocidos por el uso de los dictados:

dabo ipse sexcentos qui uniuersam encyclopaediam, cum adhuc nulla esset omnino dictatorum memoria, sunt cum summa laude consecuti: Lo-

${ }^{32}$ Palmireno intituló sus discursos Laurenti Palmyreni Orationes duae aduersariae quarum prior dictata quae uocant miris laudibus extollit, altera uero acerbo conuicio reprehendit. In Academia Valentina MDLXXII recitata prior a Petro Peralta, posterior a Francisco Tarrega (142). La ley contra los dictados fue promovida durante el rectorado de Blas Navarro (165) y aprobada por el Consejo de Valencia (167). Sobre la práctica de los "dictata" en la Universidad de Valencia, véase Cea, "Introducción" a su edición de los Discursos latinos de Palmireno, L-LI.

${ }^{33}$ Sobre las reformas realizadas en dicho periodo, Cfr. Febrer, Ortodoxia.

${ }^{34}$ Sobre la biografía de Pedro Juan Núñez, véase López Rueda, Helenistas, 354-355.

35 "¿Quién nos dio a conocer a Polo, muy ilustre doctor en Medicina, a Pascual en Filosofía, y a Viñas en Oratoria? Los dictados de Núñez" (Discursos, 151). Todas las traducciones de la citada obra están tomadas de la versión de M. J. Cea. 
doicus Vives, Gelida, Strany. eloquentiae et philosophiae ornamentum Petrus Ioannes Nuñesius (Discursos, 176). ${ }^{36}$

Constata, en fin, la afición de Núñez por esta forma de enseñanza el propio título de sus ejercicios retóricos, dados a la imprenta de forma independiente en Zaragoza en 1596 y donde se identifica el contenido del libro con los apuntes que el humanista impartía a sus alumnos: Progymnasmata, id est, praeludia quaedam oratoria ex progymnasmatis potissimum Aphthonii, dictata a Petro Ioanne Nunnesio Valentino.

Así pues, Núñez escogió como tema para el ejemplo de propuesta de ley un asunto de legislación académica que le tocaba muy de cerca y que le permitía descalificar las razones por las que se había prohibido el uso de la metodología docente que él mismo practicaba. El humanista colocó el ataque a la ley contra los dictados a renglón seguido de las instrucciones para la composición del ejercicio, a las que ya me referí anteriormente y donde se preceptuaba el exordio, el argumento contrario, el uso de contradicciones y soluciones y el epílogo, pero no se mencionaban los principios de argumentación aftonianos. Sin embargo, dichos principios jugaron un papel determinante en la construcción de su estructura, como muestra el siguiente análisis detallado del discurso:

1. El argumento "a iusto" es la base de la primera objeción y su correspondiente solución. El humanista aduce que se acusa injustamente a los dictados de la falta de laboriosidad de los estudiantes, aunque son los propios alumnos y no el método quienes deben cargar con dicha culpa:

Oppositio 1. At enim istis dictatis auditores redduntur negligentiores. Concessio. Fiunt quidem negligentiores; culpam certe nulla dictata, omnem uero auditores sustinebunt. Exterminetur isto pacto eloquentia quod plerique clarissimi oratores suo, non artis uitio rempublicam dominatione oppresserint; relegetur in ultimas gentes philosophia, quod philosophi

36 “yo citaré mil que han alcanzado con mucha gloria el saber universal, aunque hasta ahora no se les recordara por los dictados: Luis Vives, Gelida, Estrany, Pedro Juan Núñez, gloria de la elocuenia y la sabiduría" (Discursos, 177). 
nobilissimi partim suorum ciuium mores corruperint, partim respublicas labefactarint $(76){ }^{37}$

2. El argumento "ab utili" es la base de la segunda objeción y su correspondiente solución. El humanista contrarresta la idea de que los dictados hacen trabajar menos a los estudiantes, argumentando que son un útil instrumento de estudio, pues, sin notas del profesor, los jóvenes no pueden resolver las dudas al memorizar en casa la materia para el examen:

Oppositio 2. At istis exscribendis multum operae illis eripitur. Concessio. Eripitur quidem, sed plus eriperetur, nisi aliquid a doctoribus auditores acciperent. Nam, cum domum redeunt, si quid in aduersaria memoriae caussa referendum sit, incerti quid sequantur, animi pendent et uehementer haesitant (77)..$^{38}$

3. El argumento "a legitimo" aparece usado en el epílogo. Al recapitular las razones que avalan la práctica de los dictados, el humanista menciona la legitimidad conferida por su uso habitual en otras naciones durante siglos: ${ }^{39}$ "Epilogus. Quare permagni interest dictata audito-

37 "Primera oposición. Pero con esos dictados los estudiantes se vuelven más descuidados. Concesión. Desde luego que se vuelven más descuidados. La culpa — puedes estar seguro - no se le puede echar a los dictados, sino toda entera a los estudiantes. Según eso, que se elimine la elocuencia, porque la mayoría de los más ilustres oradores por falta propia y no de su arte hayan atacado al estado; que se relegue a los confines del mundo a la filosofía, porque brillantísimos filósofos hayan traído unos la corrupción a las costumbres de sus ciudades, y otros hayan arruinado las repúblicas".

38 "Segunda oposición. Pero con esas explicaciones escritas se les quita una gran parte del trabajo. Concesión. Se les quita, desde luego, pero más se les quitaría si los profesores no se las dieran. Pues, al volver a casa, si tienen que repasar algo a fin de memorizarlo para los exámenes, cuando no tienen claro cuál es el hilo que están siguiendo, se quedan atascados y sumidos en un mar de dudas".

${ }^{39}$ Uno de los argumentos usados en la polémica universitaria valenciana para desvalorizar los dictados era que no se usaban en ningún otro centro docente español. Como ya se ha visto, Núñez contrarresta este argumento aduciendo que venían respaldados por una tradición de siglos en diferentes países. Palmireno también refuta la idea de que los dictados solo se usaban en Valencia y no en otras universidades españolas aduciendo que su Universidad siempre había ayudado a los estudiantes, para los cuales la disponibilidad de apuntes era una útil herramienta el día que no podían asistir a clase (Palmireno. Discursos latinos, 156). 
ribus proponere, cum in consuetudine et more omnium gentium et saeculorum hoc positum esse uideamus" (77-78). ${ }^{40}$

4. El argumento "a possibili" (también conocido como "a facili”) cierra el epílogo. El humanista recuerda que el uso de apuntes del profesor hace más fácil la memorización y la retención de los conocimientos: "Accedit etiam quod isto beneficio dictata facilius memoriae mandari et infixa haerere possunt" (78). ${ }^{41}$

El modelo construido por Núñez era, sin duda, un ejercicio escolar, ideado para que los alumnos vieran con claridad cómo ir entremezclando los principios de argumentación con los bloques de objeciones y soluciones. En cambio, las citadas Orationes aduersariae de Palmireno, con las que guarda una innegable relación, ya no eran sencillos modelos para aprendices. Se trataba de elaborados discursos académicos centrados en la defensa o ataque de una ley, cuyo esqueleto no era fruto del talento inventivo natural del escritor, sino de su capacidad para elaborar un texto literario a partir de una receta practicada en ejercicios de nivel inferior. $^{42}$

Un caso claro es el discurso que atacaba la promulgación de la ley contra los dictados. El conocimiento de la preceptiva de la legislatio explica que el humanista, tras un largo exordio donde trata de captar el favor y la atención de los Jurados valencianos y del Rector de la Universidad, introduzca una "confirmatio" basada en bloques de objeciones y soluciones y en los principios argumentativos de antigüedad, prestigio

40 "Epílogo. Por lo cual es de gran interés ofrecer apuntes a los estudiantes, dado que vemos que esta práctica se ha usado tradicionalmente y ha formado parte de las costumbres de todas las naciones y de todas las épocas".

41 "A ello también se añade que gracias a esa buena relación las explicaciones dictadas pueden memorizarse con mayor facilidad y quedarse fijadas". Palmireno da la vuelta a este argumento al señalar que los alumnos solo tienen en la memoria lo que está en los apuntes (168).

${ }^{42}$ En el consejo octavo de la Segunda Parte del Latino de repente (1573), donde incluyó los progymnasmata, Palmireno declara la importancia que la ejercitación mediante este método había tenido en su fluidez compositiva: "Lo que a mí me valió mucho para no estar mudo [...] es exercitarte muchos días en los progymnasmas de Aphthonio" (38) e informa de que enseñaba estos ejercicios mediante la técnica del dictado: "El cual cada año dicto a mis discípulos con diversos exemplos en latín" (38). 
y utilidad: "Concedite, quaeso, ut paucis haec tris de antiquitate, dignitate et utilitate confirmem" (Discursos latinos, 144). ${ }^{43}$

El principio de antigüedad no era sino una variante del de legitimidad, como indica Prisciano ("legitimus, si dicamus quod contra ueteres leges", Institutionum 12, 34, 440), cuya versión de los ejercicios de Hermógenes conocía bien Palmireno (Pérez Custodio, "La recepción"). El de dignidad no es sino el principio de estimación según Teón (Ejercicios, 150), cuyo texto el humanista también conocía (Pérez Custodio, "Los progymnasmata de Teón"), o de adecuación en palabras de Prisciano ("decenti, quando dicimus, quod ingloriosum est", Institutionum $12,34,440)$. El de utilidad es un principio, como ya se ha visto, mencionado por Aftonio.

Con estos elementos Palmireno construyó su ataque a la ley contra los dictados como sigue: ${ }^{44}$

1. Principio de antigüedad (o legitimidad), IX, 4-5: Enumeración de ejemplos de prestigiosos sabios de la antigüedad que utilizaron en su docencia la práctica del dictado (Pitágoras, Aristóteles, Aulo Gelio y Cicerón). El dictado se describe como una práctica heredada de tiempos heroicos ("rem ab heroicis ductam temporibus").

2. Principio de utilidad, IX, 6-7: Desarrollo de la idea de que los dictados sirven para cultivar la habilidad de la escritura. La identificación del argumento es específica en la referencia al sinfín de utilidades que emanan de los dictados ("sexcentas utilitates ${ }^{45}$ quas experimento docti intelleximus ex dictatis emanare").

3. Objeción 1 y su solución, IX, 8: Se objeta que muchos sabios no se formaron con la práctica del dictado. Se responde que, aunque así sea

43 "Permitidme, por favor, que en pocas palabras confirme estas tres cuestiones acerca de su antigüedad, prestigio y utilidad" (145).

${ }^{44}$ Sigo la división del texto que aparece en la edición de Cea, donde IX identifica la posición de este discurso en el corpus editado y los números arábigos sirven para localizar los parágrafos.

${ }^{45}$ Como es bien sabido el numeral seiscientos se usa en latín para indicar una cifra muy alta pero indeterminada. Así, por ejemplo, se constata su uso en el Renacimiento en la referencia de Erasmo de Rotterdam al cúmulo inmenso de desgracias que pueden asaltar la vida humana (Adagia, 2, 3, 48: "sexcenta morborum genera quotidie infestant"). 
en algunos casos, hay también muchos que alcanzaron la erudición gracias a ellos.

4. Objeción 2 y su solución, IX, 9: Se objeta que pocos profesores han adquirido renombre con el uso del método. Se responde con una larga lista de los que sí lo alcanzaron, entre ellos, Pedro Juan Núñez.

5. Recapitulación de lo expuesto y tránsito hacia la tercera objeción, IX, 10.

6. Objeción 3 y su solución, basada en el principio de estimación, IX, 11. Se objeta que las otras universidades españolas ${ }^{46}$ no admiten el uso de los dictados. Se responde que ello se produce por falta de generosidad, una cualidad de que hace gala el Studi valenciano cuando acoge a estudiantes venidos de otras regiones y les facilita los dictados para que no se queden atrás en caso de faltar a clase. El uso de los dictados es una muestra, según Palmireno, de la grandeza de la universidad, que sabe adaptarse a las necesidades de los alumnos desfavorecidos y ofrecerles su afecto y ayuda.

El paralelismo entre la arquitectura del discurso del humanista y lo prescrito para la propuesta de ley aleja, a mi parecer, toda duda sobre la dependencia de la creación literaria y el entrenamiento previo en recetas más sencillas.

Me referiré, por último, al ejemplo de "legislatio" que se lee en los ejercicios del jesuita Bartolomé Bravo salidos en Pamplona en 1589. El tema de la composición, "Legis refutandae exemplum: Princeps solutus est legibus", desarrollaba la refutación de una norma del derecho romano que establecía la desvinculación del príncipe respecto a las leyes. Esta cuestión rebasaba el simple gusto por las antigüedades y constituía un tema de efervescente actualidad en la filosofía política del momento, al plantear la necesidad de poner límites al uso arbitrario del poder. El debate sobre la materia contaba con una larga trayectoria en afamados glosadores y comentaristas del derecho romano, ${ }^{47}$ entre ellos Budé, que

${ }^{46}$ Palmireno menciona las siguientes: Salamanca, Alcalá, Sevilla, Toledo, Huesca, Lérida y Barcelona (157).

${ }^{47}$ Sobre las distintas formulaciones de este principio legal en los glosadores del derecho romano, véase Braun, Juan de Mariana, 78-79. 
había analizado tiempo atrás las distintas aristas de la citada formulación (Annotationes, fol. XLI r.-v.). Pero la cuestión, además, era un tema de peso en el ideario de la Compañía de Jesús, que se postuló en defensora del sometimiento del monarca a la ley. A exponer todos los argumentos en contra de esta antigua ley dedicó el padre Juan de Mariana el capítulo I, 9 de su De rege et regis institutione libri III (1599), la obra donde se encargó de analizar lo relativo a la institución monárquica y a la educación del rey. ${ }^{48}$

Pues bien, Bartolomé Bravo, como sus antecesores, reveló a los estudiosos la estructura interna de su modelo mediante glosas marginales, que permiten saber que el jesuita había redactado esta pieza escolar siguiendo estrictamente la división establecida por Aftonio en los cuatro principios de argumentación (exordio, argumento "a contrario", argumentos "a legitimo", "a iusto", "ab utili" y "a facile", y epílogo), sobre los que había informado con pulcritud en las instrucciones preliminares:

Tractatur uero primum proëmio, quod constare poterit breui ipsius legis uel laude, uel uituperatione. Huic subiicietur contrarium, ut aliquod scilicet argumentum ex eo quod contrarium sit legi, eliciatur ad eam uel confirmandam, uel reprehendendam. Deinde ex his locis reliquam aut comprobationem aut consultationem petes: legitimo, ut id ipsum legibus uel diuinis uel humanis cautum esse doceamus; iusto, ut legis aequitatem ostendamus; utili ac possibili, quibus rei utilitas facilitasque proponatur. Si quid uero obiici possit, eidem nobis occurrendum ac respondendum erit. Cum reprehendenda lex est, loca erunt superioribus contraria $(52 \mathrm{v} .-53 \mathrm{v}.){ }^{49}$

${ }^{48}$ El capítulo abarca las páginas 99-107. Sobre los argumentos desplegados por Mariana, véase Braun, Juan de Mariana, 77-80.

49 "Se amplifica primero mediante un proemio, que podrá constar de una breve alabanza o vituperio de la propia ley. A esto se añadirá el argumento contrario, que consiste en sacar algún argumento de aquello que es contrario a la ley para confirmarla o refutarla. Luego tomarás de estos lugares el resto de la confirmación o tesis: del de legitimidad, a fin de hacer ver que precisamente eso está regulado por las leyes divinas y humanas; del de justicia, a fin de mostrar la equidad de la ley; del de utilidad y posibilidad, mediante los cuales se expone la utilidad y facilidad del asunto. Pero en caso de que se pueda objetar algo, deberemos hacerle frente y responderlo. Cuando se trata de refutar una ley, los lugares serán los contrarios a los anteriores". 
La comparación entre la pieza del padre Bravo y la ya citada del padre Mariana sirve, además, para descubrir la adaptabilidad de esta receta en la composición de textos literarios. El propio título del capítulo del De rege, "Princeps non est solutus legibus", es indicativo de que su contenido no es sino una refutación del antiguo principio del derecho romano que eximía al príncipe del sometimiento a la ley ("Princeps solutus est legibus"). Los textos de Bravo y de Mariana tratan, pues, la misma materia, pero desde dos perspectivas distintas: el de Bravo ataca la antigua norma, mientras que el de Mariana defiende la formulación opuesta de la misma.

El cotejo de los argumentos y la estructura de ambas piezas dejan ver a las claras que el capítulo del padre Mariana, un texto literario de filosofía política, está compuesto mediante una serie de recursos semejantes a los usados en un nivel compositivo inferior por Bravo. Así pues, el capítulo noveno del libro primero del De rege no puede considerarse como resultado de la creatividad "a nihilo" del jesuita, sino de su pericia en la aplicación de una estrategia previamente aprendida y cuya presencia es rastreable. Como ya se ha visto, el conocimiento de las antiguas instrucciones para desarrollar el ataque o la defensa de una ley proporcionaba una estructura compositiva caracterizada, de una parte, por la presencia de argumentos para confirmar o refutar la ley, y, de otra, por la inserción de bloques de objeciones y soluciones con los que recoger las tesis contrarias y rebatirlas. Ambos elementos están presentes en el texto de Mariana, como intentaré mostrar a continuación:

\section{La presencia de los principios de argumentación. Los distintos} argumentos, aunque arropados por la elaboración propia de un texto literario, son identificables gracias a ciertas marcas léxicas y a la comparación de los mismos con los pasajes correspondientes en el modelo de Bravo. Así, por ejemplo, se puede distinguir el uso de los siguientes:

1.1. El argumento "a difficili": Es el contrario del argumento "a facili" o "a possibili" y sustenta la introducción al advertir al lector de la dificultad de persuadir al príncipe de sus límites. La marca léxica que permite identificar el argumento es el adverbio "difficile": "Suadere difficile, ne bonorum affluentia corrupti et uanis aulicorum sermo- 
nibus inflati, ad dignitatis suae statum, maiestatis amplificationem pertinere putent augere opes et potentiam" $(100) .{ }^{50}$

1.2. El argumento "a contrario": Sigue al anterior y señala que, contrariamente a lo que el príncipe pueda creer, nada es más provechoso para la institución real que su sometimiento a la moderación y a la moral. La marca léxica que lo identifica es el adverbio "contra": "Cum contra res habeat" (100). ${ }^{51}$

1.3. El argumento "a legitimo": Enlaza con el precedente para establecer que el príncipe debe dar cuenta de sus actos a Dios, que avala su poder: "si fixum fuerit animo atque intimis medullis impressum ita principes imperare ut seruiant, consiliorum et uitae posituri rationem, primum Deo, cuius nutu sola terrarum gubernantur, imperia stabiliuntur caduntque" (100). ${ }^{52}$

El recurso al argumento de legitimidad basado en que el rey debe someterse a la misma ley que sus súbditos por orden divina está documentado en el modelo de Bravo, quien aduce un pasaje del Ecclesiastes e identifica la naturaleza de este argumento en anotación marginal:

A legitimo. Quare summus ille legislator Deus rerum publicarum moderatores pari cum suis ciuibus iure esse debere non obscure docet, eosque monet, ita quidem existiment non se excelso loco constitutos ad miseros homines suis imperiis ac legibus opprimendos, sed ut clarissimum lumen, quo uirtutis et honestatis uia caeteris illustrior appareat atque facilior (117) ${ }^{53}$

50 "Es difícil convencerles de que, estando corrompidos por la afluencia de bienes y henchidos por las vanas palabras de los cortesanos, no piensen que aumentar sus riquezas y su poder es algo que concierne al mantenimiento de su categoría y al engrandecimiento de su majestad".

51 "Puesto que es al revés".

52 "Si tuviera fijo en su mente e impreso en lo más profundo de su corazón que los príncipes gobiernan de manera que, dispuestos a dar razón de sus decisiones y de su vida, estén en primer lugar al servicio de Dios, cuya voluntad gobierna la superficie de la tierra, consolida los estados y los hace caer".

53 “Argumento de legitimidad. Por lo cual Dios, el sumo legislador, enseña sin sombra de duda que los que gobiernan el estado deben someterse al mismo derecho que sus ciudadanos, y les advierte que así consideren que no han sido colocados en el puesto más alto para oprimir a los hombres desgraciados con sus órdenes y leyes, sino para ser 
1.4. El argumento "a decenti", es decir, argumento de estimación o dignidad, que establece la repercusión en la reputación. Mariana lo hilvana con el anterior al condicionar la buena fama del monarca tras su muerte a un comportamiento moderado y sometido a la ley durante la vida. El elemento léxico que permite identificar el argumento es el término "fama": "ac frequenter cogitandum quid fama post sexcentos nempe annos locutura sit" (100). ${ }^{54}$

1.5. Argumento "a utili”. Mariana defiende que el ejemplo del príncipe observante de las leyes redunda en la estabilidad de las mismas y en la obediencia de los súbditos: "Postremo sit principi persuasum leges sacrosantas, quibus publica salus stat, tum demum fore stabiles, si suo ipse eas exemplo sanciat" (101)..$^{55}$

Este argumento aparece formulado con interesantes coincidencias léxicas en el modelo de Bravo, donde se indica su naturaleza en anotación marginal:

A utili. Qui ergo suam uelit rempublicam in pace, in ciuium amore erga se et charitate gubernare, leges a se constitutas apud suos ciues maximam uim habere, eisdem gratas esse, ab illis diligenter seruari, ostendat illas a se plurimi fiere, non uerbis solum atque poenarum metu, quod satis non est, sed multo magis exemplo (117r.-118v.). ${ }^{56}$

1.6. El argumento "a iusto" sigue al anterior y establece que el quebrantamiento de la ley por parte del príncipe le aparta del concepto

la brillantísima luz con la que el camino de la verdad y la moralidad se muestre más diáfano y fácil a los otros".

54 "Y hay que pensar a menudo qué va a decir la fama después de mucho tiempo". Sobre el significado el número seiscientos, véase nota 45.

55 "Finalmente, que el príncipe esté convencido de que las leyes sacrosantas, en las que reside la salvación de todos, quedarán consolidadas en el momento en que él mismo las ratifique con su ejemplo".

56 "Argumento de utilidad. En consecuencia, quien quiera gobernar su estado en medio de la paz, del amor de los súbditos hacia su persona y de la caridad, y quiera que las leyes por él establecidas tengan la mayor autoridad ante sus súbditos, les sean gratas y merezcan el diligente respeto de aquellos, debe mostrar que él las considera importantísimas no solo con sus palabras, ni con el miedo al castigo, porque no es suficiente, sino mucho más con su ejemplo". 
de justicia y honradez. Los términos "aequitate" y "probitate" permiten identificar sin ambigüedades la naturaleza del argumento:

Cum enim fas iusque legibus contineatur in omni uitae parte, qui leges uiolat $\mathrm{ab}$ aequitate discedat et a probitate necesse est. Quod nulli conceditur, regi multo minus, cuius cura et potestas aequitate sancienda, uindicanda prauitate consumitur, eoque curae imperandi et cogitationes referendae sunt (101). ${ }^{57}$

En el texto de Bravo, además de la anotación marginal, los términos "iustitia", "aequitas" y otros de la misma etimología, como "aequum", "iniquae", "aequitorum" y "iustiorum", ayudan a descubrir ante qué argumento se encuentra el lector:

A iusto. Iam uero quam aequum sit bonum principem ita se gerere, ut suorum ciuium leges suas esse putet, iisque se ut caeteros constringi gaudeat, ipsa legum aequitas docet. Nam si iniquae quidem sunt, non eae leges, sed libidines principis flagitiosaque decreta existimari debent; si uero ex una iustitia et aequitate constituantur, quem aequiorem ac iustitiorem in sua republica malle quam se ipsum debet? (117r). ${ }^{58}$

Los argumentos mencionados vuelven a recapitularse luego en el epílogo, donde, a modo de recordatorio, Mariana repasa cuáles deben ser los pilares de la educación del monarca respetuoso con la ley. Estos pilares se basan en los argumentos de:

(legitimidad: Debe inculcarse al príncipe la conciencia de que apartarse de la ley es cometer un delito contra Dios. El jesuita ya

57 "Puesto que el derecho divino y humano está recogido en las leyes en lo relativo a todos los aspectos de la vida, el que viola las leyes se aparta necesariamente de la justicia y de la moralidad. Lo que a nadie se permite, mucho menos debe permitirse al príncipe, cuyo empeño y poder se emplean en la sanción de la justicia y en la punición de la maldad, y a ello debe dedicar los empeños y pensamientos de su gobierno".

58 "Argumento de justicia. Pero ya la propia equidad de las leyes enseña qué justo es que el buen príncipe se comporte de modo que piense que las leyes de sus ciudadanos son las suyas y se congratule de estar sujeto a ellas igual que los demás. Pues si son injustas, no deben considerarse leyes, sino caprichos de príncipe y decretos vergonzantes; si, por el contrario, nacen tan solo de la justicia y la equidad, ¿hay alguien en su república a quien pueda considerar por delante de sí en equidad y justicia?”. 
señaló anteriormente que la ley divina ordena al rey someterse a las mismas normas que sus súbditos: "Inculcetur [...] graui se religione implicare, si repugnet" (107). ${ }^{59}$

* utilidad: El ejemplo del príncipe y no el miedo al castigo es la clave para la obediencia de los súbditos: "Inculcetur [...] esse legum custodem et uindicem, quod exemplo magis faciet quam metu, qui officii diuturnus magister non est" (107). ${ }^{60} \mathrm{El}$ término clave vuelve a ser "exemplo". La similitud con el argumento de no recurrir al miedo ya desplegado por Bravo resulta llamativa.

(6) facilidad: El príncipe que se somete a las leyes gobierna con muchas más facilidad el estado: "Si legibus se astrictum profitebitur, rempublicam facillime gubernabit" (107). ${ }^{61} \mathrm{El}$ término identificador del argumento es el adverbio "facillime".

* estimación: Mariana argumenta que la majestad del príncipe, es decir, el respeto de que goza, no disminuye con su sometimiento a la ley; antes bien, la capacidad de violar la ley puede desencadenar su locura: "At principis maiestas ea modestia imminuetur. Imo augebitur amentia, libertate uiolandi leges concessa" (107). ${ }^{62} \mathrm{~A}$ este argumento sigue otro de la misma naturaleza: el jesuita niega que temer las leyes deba ser considerado como signo de un espíritu depravado y afirma que, por el contrario, ha de ser considerado como tal el que las desprecia: "Praui, inquis, et obnoxii animi est uereri leges. Imo profligati atque contumacis eas despicere" (107) ${ }^{63}$

\section{La presencia de los bloques de objeciones y soluciones. El padre} Mariana se sirve de este recurso para desarticular los argumentos que pueden atacar su tesis. El tono de debate argumentativo se recoge mediante la interpelación a un oponente, como sucede en la siguiente oposición: "At ridiculum esse ais, qui opibus et potentia caeteris

59 "Que se le inculque que comete un grave pecado si la desobedece".

60 "Que se le inculque que es el guardián y el defensor de las leyes, lo que hará más con el ejemplo que con el miedo, que no es maestro de una obediencia duradera".

${ }^{61}$ "Si afirma que se somete a las leyes, gobernará con la mayor facilidad el estado".

62 "Pero la majestad del príncipe disminuirá con esa moderación. Todo lo contrario, aumentará su desvarío si se le concede la libertad de violar las leyes".

${ }^{63}$ "Temer a las leyes, dices, es propio de un espíritu perverso y sumiso. Todo lo contrario, su desprecio es típico del espíritu depravado e insolente". 
praestat, eum legibus uelle subiicere, iure exaequare aliis" $(105){ }^{64}$ seguida de su correspondiente solución: "Nam lex aequalitatem sancit: quid enim aliud est aequitas? Inter eos ergo qui omni ex parte sunt inaequales habere locum non potest" (105). ${ }^{65}$

Un caso similar es el del encadenamiento de varias oposiciones: "Deinde ineptum uideri ais illigare legibus quem metu supplicii et iudiciorum coercere non possis [...] Frustra enim leges sint, nisi maioris potestatis metu stabiliantur. Postremo multae sunt leges quae ita multitudinem constringunt, ut in principem non conueniant [...]" (105), ${ }^{66}$ recogidas por una solución: "Verum id est, neque ita amentes sumus, ut reges in fastigio collocatos de gradu deiicere, in turbamque mittere conemur. Non ea nostra mens est legibus omnibus sine discriminatione principem esse subiectum, sed [...]" (105). ${ }^{67}$

Las huellas dejadas por la receta retórica de la legislatio en el texto del padre Mariana, a mi parecer, son bien visibles y difíciles de negar. Explican por qué ese capítulo fue compuesto de una determinada manera e ilustran el impacto de un entrenamiento retórico que proporcionó al erudito jesuita los instrumentos argumentativos necesarios para construir un texto de admitido valor literario y altura intelectual reconocida.

Llego ya al final. Los materiales presentados en este trabajo han pretendido mostrar que la legislatio fue, como muchas otras cuestiones en el terreno de los progymnasmata, objeto una recepción e interpretación dificultosa, pero que el esfuerzo de los pedagogos por hacer entendible la antigua preceptiva, explicar la arquitectura del ejemplo de Aftonio y componer otros modelos que sirvieran de guía a los estudiantes puso en

${ }^{64}$ "Pero dices que es ridículo que quien supera a los demás en riqueza y poder quiera someterse a las leyes e igualarse en derecho con los otros".

65 "Veamos, la ley decreta la igualdad: ¿qué otra cosa es la equidad? Por ello, entre los que son desiguales en todos los sentidos, no puede haber lugar para ella".

${ }_{66}$ "Dices luego que te parece una idiotez someter a las leyes a quien no puedes reprimir con el miedo al suplicio o a los juicios [...] pues las leyes no tendrían efectividad si no se sustentaran en el miedo a un poder mayor. Por último, son muchas las leyes que sujetan a la multitud de manera que no son aplicables al príncipe [...]".

${ }^{67}$ "Eso es verdad, y no soy tan insensato que pretenda degradar a los reyes que están situados en la más alta posición y mandarlos al populacho. Mi postura no es que el príncipe esté sujeto a todas las leyes sin discriminación, sino [...]”. 
manos de estos unos recursos retóricos de avalada eficacia que pasaron de los manuales docentes a los textos literarios. Por ello me parece que hay razones sobradas para sostener que cuanto más sepamos de cómo se entendieron, enseñaron y practicaron los antiguos progymnasmata en el XVI, mejor podremos comprender cómo se escribieron los grandes textos de las letras europeas.

\section{REFERENCIAS}

Ediciones de textos y traducciones (en obras con distintas reimpresiones se cita aquella que se ha manejado)

Artaza, Elena, Antología de textos retóricos españoles del siglo XVI, Bilbao, Universidad de Deusto, 1997.

Agricola (Huisman), Rudolf, De inuentione dialectica libri omnes et integri et recogniti, qui iam olim quidem in publicum prodierunt, sed trunci ac mutili nec minus item deprauati, nunc demum ad autographi exemplaris fidem per Alardum Aemstelredamum accuratius emendati et addidits annotationibus illustrati, Colonia, I. Gymnicus, 1539.

Agricola (Huisman), Rudolf, Aphthonii sophistae progymnasmata Rhetorica, Salamanca, A. de Portonaris, 1550.

Bravo, Bartolomé, Progymnasmata siue Praeexercitationes oratoriae cum singulis cuiusque progymnasmatis exemplaribus, Pamplona, T. Porral, 1589.

Budé (Budaeus), Guillaume, Annotationes in quattuor et uiginti Pandectarum libros ad Ioannem Deganaium Cancellarium Franciae, Paris, I. Badio, 1508.

Cataneo (Cataneus), Giovanni M., Aphthonii Progymnasmata, id est, praeexercitationes rhetorum, et Luciani opusculum De componenda Historia nuper a Ioanne Maria Cataneo latinitate donata et ad utilitatem legentium nunc primum publicata solertique diligentia emendata, Venecia, L. Lori, 1522.

Erasmo, Desiderio, Adagiorum opus ex postrema auctoris recognitione, Lyon, S. Gryphe, 1550.

Escobar, Francisco de, Aphthonii sophistae Progymnasmata, hoc est, primae apud rhetorem exercitationes Francisco Scobario interprete, quibus accesit eiusdem de fabula commentatio et quarumdam exercitationum exempla, Barcelona, Claudio Bornaz, 1558.

Felten, Joseph, Rhetores Graeci XI, Leipzig, Teubner, 1913. 
KAMMERMEISTER (CAMERARIUS), Joachim, Elementa rhetoricae siue capita exercitationum studii puerilis et styli ad comparandam utriusque linguae facultatem, Leipzig, Vögelin, 1562.

Kammermeister (CAMERARIUS), Joachim, Aphthonii Libellus progymnasmatum, id est praeparantium exercitationum in sermonem latinum conuersus, Graeco scripto et exemplis compluribus additis, Bamberg, Vogelin, 1567.

KAMmermeister (CAMERARIUS), Joachim, Theonis sophistae primae apud rhetores exercitationes, innumeris quibus scatebant antea mendis Ioachimi Camerarii Pabergensis opera purgatae et in sermonem latinum conversae, Basilea, Oporino, 1541.

LORICH (LORICHIUs), Reinhard, Aphthonii sophistae progymnasmata, partim a Rodolpho Agricola, partim a Ioanne Maria Cataneo latinitate donata cum luculentis et utilibus in eadem scholiis Reinhardi Lorichii Hadamarii, Lyon, Gryphe, 1598.

Lull (Lulluus), Antonio, Progymnasmata Rhetorica, Lyon, Rovillé, 1572.

Mal LARA, Juan de, In Aphthonii progymnasmata scholia ad Illustrissimum Aluarum Portogallium, Comitem Geluensem, Sevilla, A. Escribano, 1567.

Manucio (Manutius), Paulo, Antiquitatum Romanarum Liber de legibus. Index rerum memorabilium. Editio postrema, Venecia, Aldo Manucio, 1569.

Mariana, Juan de, De rege et regis institutione libri III ad Philippum III Hispaniae Regem Catholicum,Toledo, Pedro Rodríguez, 1599.

NúÑEz (Nunnesius), Pedro Juan, Progymnasmata, id est, praeludia quaedam oratoria ex progymnasmatis potissimum Aphthonii, dictata a Petro Ioanne Nunnesio Valentino, Zaragoza, M. Eximino Sánchez, 1596.

Palmireno, Juan Lorenzo, Segunda parte del Latino de repente, donde están las pláticas, exercicios y comento sobre las Elegancias de Paulo Manucio. Hay también Palmyreni Index, que es breve comentario sobre las Epistolas de Cicerón ad Familiares, Valencia, P. de Huete, 1573.

Palmireno, Juan Lorenzo, Discursos latinos, María José Cea Galán (ed.), Alcañiz-Madrid, Instituto de Estudios Humanísticos-Laberinto-Consejo Superior de Investigaciones Científicas, 2009.

Patillon, Michel y Giancarlo Bolognesi, Aelius Theon. Progymnasmata, París, Les Belles Lettres, 1997.

Pérez de Toledo (Petreius), Juan, Progymnasmata Artis Rhetoricae Ioannis Petreii Toletani una cum annotationibus in Senecae declamationes, controuersias et deliberatiuas, Alcalá, Juan de Brocar, 1539.

Priscianus, Institutionum Grammaticarum libri XVIII, vol. II, Leipzig, Teubner, 1858 (reproducción facsímil en Hildesheim-New York, Georgge Olms Verlag, 1981). 
Redondo Moyano, María Elena, "Nicolao de Mura. Progymnasmata", en Guadalupe Lopetegui Semperena, María Teresa Muñoz García de Iturrospe y María Elena Redondo Moyano, Antología de Textos sobre Retórica (ss. IV-IX), Bilbao, Universidad del País Vasco, 2007, 73-148.

Sánchez de las Brozas (Sanctius Brocensis), Francisco, Aphthonii Sophistae progymnasmata Rhetorica Rodolpho Agricola Phrisio interprete cum scholiis nuper additis per Franciscum Sanctium Brocensem Rhetorices professorem, Salamanca, Andrés de Portonaris, 1556.

Sánchez de las Brozas (Sanctius Brocensis), Francisco, Francisco Sánchez de las Brozas: Aphthonii sophistae Progymnasmata rhetorica. Ejercicios de retórica del rétor Aftonio. 1556, Jesús Ureña (ed.), en Miguel Ángel Garrido (ed.), Retóricas españolas del s. XVI escritas en latín, edición digital, Biblioteca Virtual Menéndez Pelayo de Polígrafos Españoles, Consejo Superior de Investigaciones Científicas-Fundación Ignacio Larramendi, 2004.

Schade (Mosellanus), Peter, De primis apud rhetorem exercitationibus praeceptiones $P$. Mosellani, primum quidem in priuatorum suorum discipulorum usum comparatae, deinde in communem adolescentum utilitatem conscriptae, Cracovia, M. Scharffenbergk, 1530.

Spengel, Leonard von, Rhetores Graeci II, Leipzig, Teubner, 1854.

RABE, Hugo, Rhetores Graeci VI, Leipzig, Teubner, 1913.

RABE, Hugo, Rhetores Graeci X, Leipzig, Teubner, 1926.

Teón-Hermógenes-Aftonio, Ejercicios de Retórica, trad. María Dolores Reche, Madrid, Editorial Gredos, 1991.

Torres, Alfonso de, Ejercicios de Retórica, Violeta Pérez Custodio (ed. y trad.), Alcañiz-Madrid, Instituto de Estudios Humanísticos-Laberinto-Consejo Superior de Investigaciones Científicas, 2003.

\section{Estudios}

ANTÓn, Beatriz, "Emblemática y didáctica del latín. Insignis pietate ciconia", Revista de Estudios Latinos, 2, 2002, 199-233.

Braun, Harald E., Juan de Mariana and Early Modern Spanish Political Thought, Hampshire, Ashgate, 2007.

ClaRK, Donald L., "The Rise and Fall of Progymnasmata in Sixteenth and Seventeenth Century Grammar Schools", Speech Monographs, 19, 1952, 259-263.

Febrer Romaguera, Manuel V., Ortodoxia y Humanismo. El Estudio General de Valencia durante el rectorado de Joan de Salaya (1525-1558), Valencia, Universidad de Valencia, 2003. 
Fruteau de Laclos, Henry, Les progymnasmata de Nicolaos de Myra dans la tradition versicolore des exercices préparatoires de rhétorique, Montpellier, Université Paul Valéry, 1999.

Gibson, Craig A., Libanius' Progymnasmata: Model Exercises in Greek Prose Composition and Rhetoric, Atlanta, Society of Biblical Literature, 2008.

JARDINE, Lisa, "Distinctive Discipline: Rudolph Agricola's Influence on Methodical Thinking in the Humanities", en Rodolphus Agricola Phrisius, 1444-1485: Proceedings of the International Conference at the University of Groningen 28-30 October 1985, F. Akkerman y A. J. Vanderjagt (eds.), Leiden, Brill, 1988.

LAnA, Ítalo, I progymnasmi di Elio Teone. Volume primo. La Storia del texto, Torino, Università di Torino, 1959.

López Rueda, José, Helenistas españoles del siglo XVI, Madrid, Consejo Superior de Investigaciones Científicas, 1973.

Merino Jerez, Luis, "El Brocense y Juan de Mal Lara: una amistad inexplorada", Revista de Estudios Latinos, 2, 2002, 149-168.

Pérez Custodio, María Violeta, "La traducción al latín de los Ejercicios de Aftonio publicada por Francisco de Escobar (1558): Algunas claves para su análisis y valoración”, Calamus renascens, 4, 2007, 121-144.

Pérez Custodio, María Violeta, “Los progymnasmata de Teón en la España del XVI", Rhetorica [en prensa].

Pérez Custodio, María Violeta, "La recepción de los ejercicios retóricos del Pseudo-Hermógenes en la España del Xvi", Humanismo y Pervivencia del Mundo Clásico V. Homenaje al Prof. Juan Gil [en prensa].

Pérez Custodio, María Violeta, "Sobre el origen de los materiales contenidos en los Progymnasmata de Palmireno", en Humanismo y Pervivencia del mundo clásico III. Homenaje al profesor Antonio Fontán, vol. 3.1, J. M. Maestre, J. Pascual y L. Charlo (eds.), Alcañiz-Madrid, Instituto de Estudios Humanísticos-Laberinto-Consejo Superior de Investigaciones Científicas, 2002, 245-259.

Ureña Bracero, Jesús, "Algunas consideraciones acerca de los escolios del Brocense a los Progymnasmata de Aftonio", en El Brocense y las Humanidades en el siglo XVI, C. Codoñer, J. Ureña y S. López Moreda (eds.), Salamanca, Universidad de Salamanca, 2003, 317-328. 